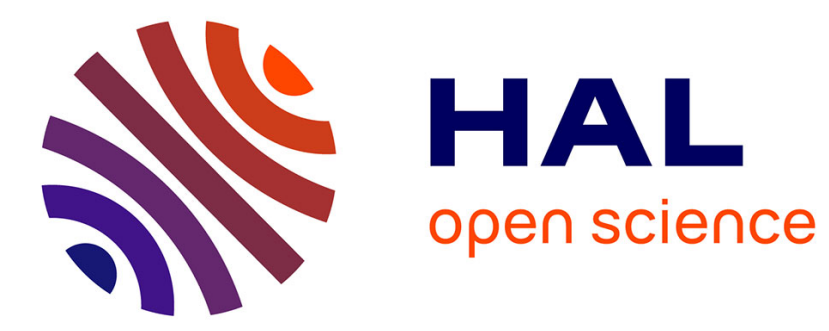

\title{
Hepatitis B virus receptors and molecular drug targets
}

Eloi Verrier, Che Colpitts, Camille Sureau, Thomas Baumert

\section{To cite this version:}

Eloi Verrier, Che Colpitts, Camille Sureau, Thomas Baumert. Hepatitis B virus receptors and molecular drug targets. Hepatol Int, 2016, 10 (4), pp.567-573. 10.1007/s12072-016-9718-5 . hal-02440080

\section{HAL Id: hal-02440080 \\ https://hal.science/hal-02440080}

Submitted on 14 Jan 2020

HAL is a multi-disciplinary open access archive for the deposit and dissemination of scientific research documents, whether they are published or not. The documents may come from teaching and research institutions in France or abroad, or from public or private research centers.
L'archive ouverte pluridisciplinaire HAL, est destinée au dépôt et à la diffusion de documents scientifiques de niveau recherche, publiés ou non, émanant des établissements d'enseignement et de recherche français ou étrangers, des laboratoires publics ou privés. 


\title{
Hepatitis B virus receptors and molecular drug targets
}

\author{
Eloi R. Verrier, Ph.D. ${ }^{1,2}$, Che C. Colpitts, Ph.D. ${ }^{1,2}$, Camille Sureau, Ph.D. ${ }^{3}$, Thomas F. \\ Baumert, $\mathrm{MD}^{1,2,4 *}$
}

${ }^{1}$ Inserm, U1110, Institut de Recherche sur les Maladies Virales et Hépatiques, 67000

Strasbourg, France; ${ }^{2}$ Université de Strasbourg, 67000 Strasbourg, France; ${ }^{3}$ INTS,

Laboratoire de Virologie Moléculaire, 75015 Paris, France; ${ }^{4}$ Institut Hospitalo-Universitaire, Pôle Hépato-digestif, Nouvel Hôpital Civil, 67000 Strasbourg, France.

\section{${ }^{*}$ Corresponding author: Prof. Thomas F. Baumert, MD; Inserm U1110, Institut de} Recherche sur les Maladies Virales et Hépatiques, Université de Strasbourg, 3 Rue Koeberlé, 67000 Strasbourg, France; Phone: +33 3688537 03, Fax: +33 3688537 24, email: thomas.baumert@unistra.fr

\section{Abstract: 111 words}

Total: 4996 words (including references) 

51 5

\section{Abstract}

Chronic Hepatitis B virus (HBV) infection is a leading cause of liver disease worldwide. Virusinduced diseases include cirrhosis, liver failure and hepatocellular carcinoma. Current therapeutic strategies may at best control infection without reaching cure. Complementary antiviral strategies aimed at viral cure, are therefore urgently needed. HBV entry is the first step of the infection cycle, which leads to the formation of cccDNA and the establishment of chronic infection. Viral entry may thus represent an attractive target for antiviral therapy. This review summarizes the molecular virology and cell biology of HBV entry, including the discovery and development of new HBV entry inhibitors, and discusses their potential in future treatment of HBV infection.

Keywords: Antiviral targets; host-targeting agents; liver; therapy; treatment. (1) (1) (1)

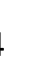

5

46
52 53 4 


\section{Introduction}

With 250-350 million affected individuals, chronic hepatitis B virus (HBV) infection is a major public health problem. Chronic HBV infection can lead to advanced liver disease such as liver cirrhosis and liver failure (1-4). Furthermore, HBV infection is a leading cause of hepatocellular cellular carcinoma (HCC) worldwide (1-4). Despite a very efficient protective vaccine, HBV prevalence has only marginally declined. Current antiviral therapies involving pegylated type-I interferon (IFN) and nucleos(t)ide analogs (NUCs) may at best control viral infection. There is no anti-HBV treatment available for efficient viral clearance in HBV carriers. HBV is a small, enveloped DNA virus of the Hepadnaviridae family, which exclusively infects human hepatocytes (4). The viral coat consists of three envelope proteins: small $S(S)$, middle $M(S+$ preS2 region) and large $L(S+$ preS2 region + preS1 region) (5). Unique features of the HBV life cycle include a genome replication mechanism that uses a reverse transcription step (targeted by NUCs) to convert pregenomic RNA to genomic DNA, and the formation of a covalently closed circular DNA (cccDNA) in the nucleus of infected hepatocytes, the equivalent of proviral DNA in retrovirus-infected cells (6). The HBV cccDNA functions as a minichromosome in the nucleus of infected cells to serve as a template for transcription into viral mRNAs. Because it is responsible for viral persistence, HBV cccDNA is the target of choice for elimination of infection (6). HBV infection in humans may become more complex when patients are co-infected with the hepatitis delta virus (HDV). HDV is a subviral infectious agent, and an obligate satellite of HBV, which uses the HBV envelope proteins to assemble infectious particles and thereby propagate with the helper HBV. As for $\mathrm{HBV}$, there is no curative treatment available (7), and chronic HBV/HDV co-infections lead to increased liver damage and HCC risk as compared to HBV mono-infections (8).

As current treatments may control, but not cure infection, new therapeutic strategies are needed, especially for treatment of chronic infections. Novel therapeutic approaches include host-targeting compounds that inhibit virus-host interactions as reviewed previously (9). As the first step of infection necessary for the formation of cccDNA and the establishment of chronic infection, viral entry represents an antiviral target in complement of 
current therapies (9-11). As HDV and HBV share the same envelope and entry pathway, targeting viral entry is of particular interest for the treatment of HBV/HDV co-infection. Here, we review the recent developments in our understanding of the HBV/HDV entry process, including the consequent new antiviral strategies.

\section{HBV entry: the quest for a viral receptor}

Although the HBV DNA replication cycle has been described in detail, molecular interactions between virus and host factors are not fully understood. One reason for this limitation has been the lack of robust cell culture infection systems for the study of the full life cycle. Viral entry can be observed in primary cultures of human hepatocytes $(\mathrm{PHH})$ and Tupaia belangeri (PTH) hepatocytes $(12,13)$. One human hepatic progenitor cell line (HepaRG) has also demonstrated susceptibility to HBV infection following DMSO-mediated differentiation, and it has been used extensively in recent years for HBV and HDV in vitro infection assays (14). However, HBV/HDV susceptible systems are limited by a number of constraints: susceptibility to infection is highly dependent on culture conditions and, in the case of $\mathrm{PHH}$, subject to donor-to-donor variability $(4,10,15)$. Besides viral entry, all other steps of the HBV or HDV replication cycles have been studied for many years in permissive hepatoma cell lines, such as Huh7 and HepG2 cells (15-18). These cell lines, however, are not susceptible to HBV and HDV infection, limiting their use to genome replication, transcription, translation, viral assembly and release, but not viral entry (19). Consequently, the HBV receptor(s) have remained unknown for many years $(20,21)$. Only in late 2012 was a first bona-fide HBV receptor identified at the basolateral membrane of differentiated human hepatocytes. Using PTH as target cells, and a labeled preS1 peptide as a bait to substitute for HBV envelope proteins, Yan et al. (22) identified the sodium taurocholate co-transporting polypeptide (NTCP), a bile-acid transporter mainly expressed at the basolateral membrane of hepatocytes (23) encoded by the SLC10A1 gene, as an HBV-specific receptor $(22,24)$. In parallel, Ni et al. (24) had compared the transcriptomic pattern of differentiated (HBV susceptible) HepaRG cells to that of undifferentiated (not susceptible) HepaRG cells, and 
112 found that NTCP mRNA was expressed upon differentiation. Interestingly, the

overexpression of human NTCP in permissive hepatoma cells such as Huh7 and HepG2 cells that lack endogenous expression of NTCP, conferred susceptibility to both HDV and HBV infection, thereby providing a cell culture model for the study of the entire HBV life cycle, including viral entry $(22,24)$.

\section{Molecular biology of HBV entry}

The interaction between HBV or HDV virions and hepatocytes begins with attachment to cell surface heparan sulfate proteoglycans (HSPGs) (25) (Figure 1). HSPGs are glycoproteins that play major roles in development and physiology (26), but they are also used for cellular attachment of numerous pathogens, including viruses (27). In the case of HBV, HSPG binding function was demonstrated by the ability of soluble heparin and other sulfated polysaccharides to impair infectivity of HDV and HBV virions $(28,29)$. Moreover, heparinase treatment of susceptible cells could inhibit HDV and HBV infection $(28,30)$. Using HepaRG cells, and a heparin-binding assay, Sureau and Salisse (30) reported that HSPGs bind to the antigenic loop of the HBV envelope protein S domain. HBV-HSPG interaction is one explanation to the highly specific tissue tropism of the virus, as viral glycoproteins recognize specific patterns of hepatic proteoglycans (including the degree of sulfation of HSPG) (25, 29). Taking advantage of NTCP-based cell culture systems and using a siRNA library targeting all members of HSPG families, Verrier et al. (31) recently demonstrated that glypican 5 (GPC5) was an attachment factor for HDV and HBV at the cell surface of hepatocytes. The involvement of GPC5 in HBV binding was confirmed by the inhibitory effect of an anti-GPC5 monoclonal antibody and by the ability of soluble recombinant GPC5 protein to neutralize HBV in vitro infection (31). GPC5 is a member of the glypican family, consisting of extracellular HSPGs bound at the cell surface through a glycosyl-phosphatidylinositol anchor (32). GPC5 carries five insertion sites (compared to three for GPC3, for instance) for highly sulfated glycosaminoglycan chains (33) and is expressed in $\mathrm{PHH}(31)$, possibly explaining the specific affinity of GPC5 for HBV virions. Since HSPG, and particularly GPC5, 
are involved in many cellular processes, including the control of cell division, growth regulation, FGF2- or Hedgehog signaling, HBV-HPSG interactions may also play a role in the pathogenesis of virus-induced liver disease $(26,33,34)$. Further studies are needed for a comprehensive overview of HSPG-HBV interactions.

Following initial attachment to HSPGs, HBV and HDV virions bind to NTCP (Figure 1). Being a liver-specific transporter, NTCP is likely to play the major role in HBV liver tropism (35). In the liver, NTCP is responsible for the transport of conjugated bile salts, typically taurocholate (36). The preS1 domain at the surface of HBV virions directly interacts with the bile acid pocket site (aa 157-165) of $\operatorname{NTCP}(22,24)$. The overlap between NTCP HBV receptor function and NTCP bile acid transporter function was confirmed by the ability of NTCP S267F mutation to disrupt not only bile acid transport but also HDV and HBV infection in a cell culture model (37). Interestingly, two genetic studies showed that the S267F SLC10A1 allele was associated with resistance to chronic HBV infection (38) and with decreased risk of cirrhosis and HCC in HBV carriers (39). However, the observation that S267F homozygous patients can still be infected by $\operatorname{HBV}(38,39)$ demonstrates that this mutation does not totally suppress HBV entry in vivo, and suggests that other hepatic factor(s) can function as surrogate HBV receptors in absence of functional NTCP. A recent study identified another domain (aa 84-87) within NTCP that plays a crucial role in HBV entry, probably at a postbinding step (40). Interestingly, the overexpression of human NTCP in non-human cells is sufficient to confer susceptibility to HDV infection, suggesting that no additional human-specific factor is required for viral attachment, fusion and trafficking of the HDV genome to the cell nucleus $(35,40)$. However, hNTCP expression in mouse cells is not sufficient to confer susceptibility to HBV infection. Using fusion between hNTCPoverexpressing mouse cells and permissive non-susceptible HepG2 cells, Lempp et al. (41) recently suggested that the absence of HBV infection was due to a lack a host factor required for HBV replication. Following NTCP binding, HBV virions are thought to be internalized by endocytosis. Both clathrin- (42) and calveolin-dependent (43) processes have 
been proposed, but to date, the detailed mechanism of NTCP-mediated internalization remains unclear.

Currently, only a limited number of host proteins are known to be involved in HBV entry, and it is expected that the new NTCP-based infection models will allow the discovery of other entry factors. Given the relatively limited percentage of infected cells in this models, despite NTCP overexpression and high multiplicity of infection $(22,24,31,44)$, it is likely that additional factors indeed play an important role at viral entry.

\section{HBV cell entry inhibitors}

Entry inhibitors have emerged as attractive candidates for prevention and treatment of chronic viral infections $(10,35)$. Interestingly, in the context of hepatitis C virus (HCV), which also leads to chronic infection of the liver, an entry inhibitor used in monotherapy was shown to cure chronic infection in human liver chimeric mice (45). It is likely that hepatocyte turnover in the absence of de novo infection results in viral clearance (45). Furthermore, broadly neutralizing anti-envelope antibodies have been shown to control and eliminate persistent HCV infection in humanized mouse models (46). Indeed, by blocking reinfection and protecting uninfected hepatocytes from de novo infection, entry inhibitors may open perspectives for novel therapeutic approaches for HBV infection.

Neutralizing antibodies targeting viral envelope epitopes were the earliest entry inhibitors explored for HBV. Hepatitis B immunoglobulin (HBIG), a mixture of polyclonal antibodies targeting the HBV S protein, is currently used to prevent liver graft reinfection in HBV-positive patients (47). Monoclonal antibodies directed against the S protein (17.1.41 and 19.79.5) were shown to reduce HBV viral load and HBsAg levels in animal models (48) and in patients in a phase I clinical trial (49), but only for several days following treatment. Interestingly, a recent study demonstrated that the administration of a novel monoclonal antiHBsAg antibody (E6F6) in a mouse model mimicking HBV infection not only suppressed the levels of HBsAg and HBV DNA for several weeks but also facilitated the restoration of antiHBV T-cell response $(50,51)$. Other monoclonal antibodies targeting the preS1 domain 
demonstrated marked anti-HBV activity in vitro (52) and in animal models (53) but have not been pursued in clinical trials.

Targeting host cell entry factors is a novel strategy that has been proposed in the context of HBV infection $(10,35)$. The attachment of HBV particles to the target hepatocyte relies on low-affinity interactions with HSPGs $(25,29)$. Small molecules that non-specifically interfere with HSPG binding therefore inhibit HBV infection. Highly sulfated compounds such as heparin (25) and suramin (54) inhibit HBV attachment by competing with cellular HSPGs for the binding sites in HBV surface proteins. GPC5 was recently identified as a HSPG possibly involved in this process (31). Indeed, a monoclonal antibody targeting GPC5 inhibited HBV infection in cell culture (31). Furthermore, synthetic anti-lipopolysaccharide peptides (SALPs) that bind to heparan sulfate moieties on the cell surface inhibit infection with a variety of enveloped viruses (55).

Since its discovery as a receptor for HBV/HDV, NTCP has been extensively explored as an antiviral target. The molecules targeting NTCP that exhibit antiviral functions against HBV are listed in Table 1. Myrcludex B, a myristoylated preS1-derived peptide, binds to NTCP and inhibits HBV infection by blocking binding of HBV to its receptor (10). PreS1derived peptides inhibit HBV/HDV infection in vivo (56), and Myrcludex B prevents HBV spread in human liver chimeric mice (57). It is currently being evaluated in a phase lla clinical trial (58). The first data suggest that Myrcludex B is well tolerated. The inhibition of HBV entry seems to be correlated with a decrease in both HBV DNA ( $>1 \log 10)$ and HDV RNA, and with an improvement of hepatic parameters (ALT) (58). Other molecules also target NTCP and inhibit HBV infection. Cyclosporin A, a cyclic peptide, interferes with HBV entry as a result of its interactions with NTCP $(44,59)$. Ezetimibe, a small molecule inhibitor of NTCPmediated bile acid uptake, also inhibits HBV/HDV entry by apparently similar mechanisms (60). Among several FDA-approved drugs with NTCP-inhibiting activity, irbesartan, a drug used for hypertension treatment, inhibited HBV infection in HepG2-NTCP cells as well as HDV infection in Huh7-NTCP cells $(61,62)$. Vanitaracin A, a tricyclic polyketide identified from a fungal secondary metabolite library, also interacts with NTCP to inhibit HBV/HDV 
infection (63). Ritonavir, an antiretroviral drug active against HIV infection, and having a putative inhibitory effect on NTCP metabolic function (64) inhibits HDV infection in Huh7NTCP cells (62). A small screen of phytochemicals identified the green tea polyphenol epigallocatechin gallate as another HBV inhibitor, which possibly interferes with HBV uptake by altering the localization and stability of NTCP (65).

\section{Conclusion and perspectives}

Chronic HBV infection is a major public health problem worldwide. Since current anti-HBV treatments do not effectively cure infection (i.e., eliminate cccDNA), novel treatment approaches are needed. Entry inhibitors may contribute to cccDNA elimination through inhibition of cccDNA synthesis and prevention of entry in non-infected hepatocytes. However, as viral entry inhibitors including host-targeting compounds do not directly target cccDNA, they should be considered as a complementary antiviral strategy in combination with other antiviral molecules, such as IFNs that can control cccDNA activity $(9,10,35,66-68)$. Recent progress in understanding the HBV entry process, particularly after the discovery of NTCP acting as a receptor, has lead to the identification of novel antiviral compounds for treatment of HBV and HDV infections. A key question will be whether entry inhibitors will help to cure HBV infection by preventing entry into cccDNA-free hepatocytes, while cccDNA-positive hepatocytes are eliminated by liver turnover. Further studies in state-of-the-art animal models and clinical trials are needed to address these questions, to ultimately establish the real place of entry inhibitors in the anti-HBV arsenal. 


\section{Compliance with Ethical Requirements}

252 Funding: This work was supported by Inserm, University of Strasbourg, the European Union

253 (EU-INTERREG-IV-Rhin Supérieur-FEDER Hepato-Regio-Net 2012; ERC-2008-AdG254 233130-HEPCENT; FP7 305600 HepaMab; EU Infect-Era hepBccc ; EU H2020 HEPCAR;

255 ERC-2014-AdG-671231-HEPCIR,), ANRS (2012/318, 2013/108) and the French Cancer

256 Agency (ARC IHU201301187). This work has been published under the framework of the

257 LABEX ANR-10-LAB-28 and benefits from a funding from the state managed by the French

258 National Research Agency as part of the Investments for the future program. CCC was

259 supported by a fellowship from the Canadian Institutes of Health Research (201411MFE-

260 338606-245517).

261 Conflict of Interest: Eloi R Verrier, Che C Colpitts, Camille Sureau and Thomas F Baumert

262 declare that they have no conflict of interest.

263 Ethical approval: This article does not contain any studies with human participants or

264 animals performed by any of the authors.

265

266

267

268

269

270

271

272

273

274

275

276

277 


\section{References}

280 1. Rehermann B, Nascimbeni M. Immunology of hepatitis B virus and hepatitis C virus infection. Nat Rev Immunol 2005;5:215-229.

2. El-Serag HB. Epidemiology of viral hepatitis and hepatocellular carcinoma. Gastroenterology 2012;142:1264-1273 e1261.

3. Thomas D, Zoulim F. New challenges in viral hepatitis. Gut 2012;61 Suppl 1:i1-5.

4. Zeisel MB, Lucifora J, Mason WS, Sureau C, Beck J, Levrero M, Kann M, Knolle PA, Benkirane M, Durantel D, Michel ML, Autran B, Cosset FL, Strick-Marchand H, Trepo C, Kao JH, Carrat F, Lacombe K, Schinazi RF, Barre-Sinoussi F, Delfraissy JF, Zoulim F. Towards an HBV cure: state-of-the-art and unresolved questions-report of the ANRS workshop on HBV cure. Gut 2015;64:1314-1326.

5. Urban S. Liver capsule: Entry and entry inhibition of hepatitis B virus and hepatitis delta virus into hepatocytes. Hepatology 2016. In press

6. Nassal M. Hepatitis B virus cccDNA - viral persistence reservoir and key obstacle for a cure of chronic hepatitis B. Gut 2015;64:1972-1984.

7. Ciancio A, Rizzetto M. Chronic hepatitis D at a standstill: where do we go from here? Nat Rev Gastroenterol Hepatol 2014;11:68-71.

8. Wedemeyer H, Yurdaydin C, Dalekos GN, Erhardt A, Cakaloglu Y, Degertekin H,

297 Gurel S, Zeuzem S, Zachou K, Bozkaya H, Koch A, Bock T, Dienes HP, Manns MP.

298 Peginterferon plus adefovir versus either drug alone for hepatitis delta. N Engl J Med 2011;364:322-331.

9. Baumert TF, Verrier ER, Nassal M, Chung RT, Zeisel MB. Host-targeting agents for treatment of hepatitis B virus infection. Curr Opin Virol 2015;14:41-46.

10. Urban S, Bartenschlager R, Kubitz R, Zoulim F. Strategies to inhibit entry of HBV and HDV into hepatocytes. Gastroenterology 2014;147:48-64.

304 11. Colpitts CC, Verrier ER, Baumert TF. Targeting viral entry for treatment of hepatitis B and C virus infections. ACS Infect Dis 2015;1:420-427. 

Hepatitis B virus infection of adult human hepatocytes cultured in the presence of dimethyl sulfoxide. J Virol 1988;62:4136-4143.

13. Walter E, Keist R, Niederost B, Pult I, Blum HE. Hepatitis B virus infection of tupaia hepatocytes in vitro and in vivo. Hepatology 1996;24:1-5.

14. Gripon P, Rumin S, Urban S, Le Seyec J, Glaise D, Cannie I, Guyomard C, Lucas J, Trepo C, Guguen-Guillouzo C. Infection of a human hepatoma cell line by hepatitis B virus. Proc Natl Acad Sci U S A 2002;99:15655-15660.

15. Dandri M, Lutgehetmann M, Petersen J. Experimental models and therapeutic approaches for HBV. Semin Immunopathol 2013;35:7-21.

16. Baumert TF, Rogers SA, Hasegawa K, Liang TJ. Two core promotor mutations identified in a hepatitis B virus strain associated with fulminant hepatitis result in enhanced viral replication. J Clin Invest 1996;98:2268-2276.

$$
\text { 17. Sells MA, Chen ML, Acs G. Production of hepatitis B virus particles in Hep G2 cells }
$$
transfected with cloned hepatitis B virus DNA. Proc Natl Acad Sci U S A 1987;84:1005-1009. 18. Ladner SK, Otto MJ, Barker CS, Zaifert K, Wang GH, Guo JT, Seeger C, King RW. Inducible expression of human hepatitis B virus (HBV) in stably transfected hepatoblastoma cells: a novel system for screening potential inhibitors of HBV replication. Antimicrob Agents Chemother 1997;41:1715-1720.

19. Glebe D, Urban S. Viral and cellular determinants involved in hepadnaviral entry. World J Gastroenterol 2007;13:22-38.

20. Engelke M, Mills K, Seitz S, Simon P, Gripon P, Schnolzer M, Urban S. Characterization of a hepatitis B and hepatitis delta virus receptor binding site. Hepatology 2006;43:750-760.

21. Gripon P, Cannie I, Urban S. Efficient inhibition of hepatitis B virus infection by acylated peptides derived from the large viral surface protein. J Virol 2005;79:1613-1622. 22. Yan H, Zhong G, Xu G, He W, Jing Z, Gao Z, Huang Y, Qi Y, Peng B, Wang H, Fu L, 
cotransporting polypeptide is a functional receptor for human hepatitis $B$ and $D$ virus. Elife 2012;1:e00049.

23. Claro da Silva T, Polli JE, Swaan PW. The solute carrier family 10 (SLC10): beyond bile acid transport. Mol Aspects Med 2013;34:252-269.

24. Ni Y, Lempp FA, Mehrle S, Nkongolo S, Kaufman C, Falth M, Stindt J, Koniger C, Nassal M, Kubitz R, Sultmann H, Urban S. Hepatitis B and D viruses exploit sodium taurocholate co-transporting polypeptide for species-specific entry into hepatocytes. Gastroenterology 2014;146:1070-1083.

25. Schulze A, Gripon P, Urban S. Hepatitis B virus infection initiates with a large surface protein-dependent binding to heparan sulfate proteoglycans. Hepatology 2007;46:17591768.

26. Bishop JR, Schuksz M, Esko JD. Heparan sulphate proteoglycans fine-tune mammalian physiology. Nature 2007;446:1030-1037.

27. Chen Y, Gotte M, Liu J, Park PW. Microbial subversion of heparan sulfate proteoglycans. Mol Cells 2008;26:415-426.

28. Lamas Longarela O, Schmidt TT, Schoneweis K, Romeo R, Wedemeyer H, Urban S, Schulze A. Proteoglycans act as cellular hepatitis delta virus attachment receptors. PLoS One 2013;8:e58340.

29. Leistner CM, Gruen-Bernhard S, Glebe D. Role of glycosaminoglycans for binding and infection of hepatitis B virus. Cell Microbiol 2008;10:122-133.

30. Sureau C, Salisse J. A conformational heparan sulfate binding site essential to infectivity overlaps with the conserved hepatitis B virus a-determinant. Hepatology 2013;57:985-994.

31. Verrier ER, Colpitts CC, Bach C, Heydmann L, Weiss A, Renaud M, Durand SC, Habersetzer F, Durantel D, Abou-Jaoude G, Lopez Ledesma MM, Felmlee DJ, Soumillon M, Croonenborghs T, Pochet N, Nassal M, Schuster C, Brino L, Sureau C, Zeisel MB, Baumert TF. A targeted functional RNAi screen uncovers Glypican 5 as an entry factor for hepatitis B and D viruses. Hepatology 2016;63:35-48. 
32. Filmus J, Capurro M, Rast J. Glypicans. Genome Biol 2008;9:224.

33. Filmus J, Capurro M. The role of glypicans in Hedgehog signaling. Matrix Biol $2014 ; 35: 248-252$.

34. Li F, Shi W, Capurro M, Filmus J. Glypican-5 stimulates rhabdomyosarcoma cell proliferation by activating Hedgehog signaling. J Cell Biol 2011;192:691-704.

35. Baumert TF, Meredith L, Ni Y, Felmlee DJ, McKeating JA, Urban S. Entry of hepatitis B and C viruses - recent progress and future impact. Curr Opin Virol 2014;4C:58-65.

36. Hagenbuch B, Meier PJ. Molecular cloning, chromosomal localization, and functional characterization of a human liver Na+/bile acid cotransporter. J Clin Invest 1994;93:13261331.

37. Yan H, Peng B, Liu Y, Xu G, He W, Ren B, Jing Z, Sui J, Li W. Viral entry of hepatitis $B$ and $D$ viruses and bile salts transportation share common molecular determinants on sodium taurocholate cotransporting polypeptide. J Virol 2014;88:3273-3284.

38. Peng L, Zhao Q, Li Q, Li M, Li C, Xu T, Jing X, Zhu X, Wang Y, Li F, Liu R, Zhong C, Pan Q, Zeng B, Liao Q, Hu B, Hu ZX, Huang YS, Sham P, Liu J, Xu S, Wang J, Gao ZL. The p.Ser267Phe variant in SLC10A1 is associated with resistance to chronic hepatitis B. Hepatology 2015;61:1251-1260.

39. Hu HH, Liu J, Lin YL, Luo WS, Chu YJ, Chang CL, Jen CL, Lee MH, Lu SN, Wang LY, You SL, Yang HI, Chen CJ. The rs2296651 (S267F) variant on NTCP (SLC10A1) is inversely associated with chronic hepatitis B and progression to cirrhosis and hepatocellular carcinoma in patients with chronic hepatitis B. Gut 2015. In press

40. Yan H, Peng B, He W, Zhong G, Qi Y, Ren B, Gao Z, Jing Z, Song M, Xu G, Sui J, Li W. Molecular determinants of hepatitis B and D virus entry restriction in mouse sodium taurocholate cotransporting polypeptide. J Virol 2013;87:7977-7991.

41. Lempp FA, Mutz P, Lipps C, Wirth D, Bartenschlager R, Urban S. Evidence that hepatitis B virus replication in mouse cells is limited by the lack of a host cell dependency factor. J Hepatol 2015. In press 
42. Huang HC, Chen CC, Chang WC, Tao MH, Huang C. Entry of hepatitis B virus into immortalized human primary hepatocytes by clathrin-dependent endocytosis. J Virol 2012;86:9443-9453.

43. Macovei A, Radulescu C, Lazar C, Petrescu S, Durantel D, Dwek RA, Zitzmann N, Nichita NB. Hepatitis B virus requires intact caveolin-1 function for productive infection in HepaRG cells. J Virol 2010;84:243-253.

44. Watashi K, Sluder A, Daito T, Matsunaga S, Ryo A, Nagamori S, Iwamoto M, Nakajima S, Tsukuda S, Borroto-Esoda K, Sugiyama M, Tanaka Y, Kanai Y, Kusuhara H, Mizokami M, Wakita T. Cyclosporin A and its analogs inhibit hepatitis B virus entry into cultured hepatocytes through targeting a membrane transporter, sodium taurocholate cotransporting polypeptide (NTCP). Hepatology 2014;59:1726-1737.

45. Mailly L, Xiao F, Lupberger J, Wilson GK, Aubert P, Duong FHT, Calabrese D, Leboeuf C, Fofana I, Thumann C, Bandiera S, Lütgehetmann M, Volz T, Davis C, Harris HJ, Mee C, Girardi E, Chane-Woon-Ming B, Ericsson M, Fletcher N, Bartenshlager R, Pessaux P, Vercauteren K, Meuleman P, Villa P, Kaderali L, Pfeffer S, Heim MH, Neunlist M, Zeisel MB, Dandri M, McKeating JA, Robinet E, Baumert TF. Clearance of persistent hepatitis C virus infection using a monoclonal antibody specific for thight junction protein claudin-1. Nature Biotechnology 2015;33:549-554.

46. de Jong YP, Dorner M, Mommersteeg MC, Xiao JW, Balazs AB, Robbins JB, Winer BY, Gerges S, Vega K, Labitt RN, Donovan BM, Giang E, Krishnan A, Chiriboga L, Charlton MR, Burton DR, Baltimore D, Law M, Rice CM, Ploss A. Broadly neutralizing antibodies abrogate established hepatitis C virus infection. Sci Transl Med 2014;6:254ra129.

47. Samuel D, Muller R, Alexander G, Fassati L, Ducot B, Benhamou JP, Bismuth H. Liver transplantation in European patients with the hepatitis B surface antigen. N Engl J Med 1993;329:1842-1847.

48. Eren R, Ilan E, Nussbaum O, Lubin I, Terkieltaub D, Arazi Y, Ben-Moshe O, Kitchinzky A, Berr S, Gopher J, Zauberman A, Galun E, Shouval D, Daudi N, Eid A, Jurim O, Magnius LO, Hammas B, Reisner Y, Dagan S. Preclinical evaluation of two human anti- 
hepatitis $B$ virus (HBV) monoclonal antibodies in the HBV-trimera mouse model and in HBV chronic carrier chimpanzees. Hepatology 2000;32:588-596.

49. Galun E, Eren R, Safadi R, Ashour Y, Terrault N, Keeffe EB, Matot E, Mizrachi S, Terkieltaub D, Zohar M, Lubin I, Gopher J, Shouval D, Dagan S. Clinical evaluation (phase I) of a combination of two human monoclonal antibodies to HBV: safety and antiviral properties. Hepatology 2002;35:673-679.

50. Zhang TY, Yuan Q, Zhao JH, Zhang YL, Yuan LZ, Lan Y, Lo YC, Sun CP, Wu CR, Zhang JF, Zhang Y, Cao JL, Guo XR, Liu X, Mo XB, Luo WX, Cheng T, Chen YX, Tao MH, Shih JW, Zhao QJ, Zhang J, Chen PJ, Yuan YA, Xia NS. Prolonged suppression of HBV in mice by a novel antibody that targets a unique epitope on hepatitis B surface antigen. Gut 2015. In press

51. Sureau C. A unique monoclonal antibody for therapeutic use against chronic hepatitis B: not all antibodies are created equal. Gut 2015. In press

52. Glebe D, Aliakbari M, Krass P, Knoop EV, Valerius KP, Gerlich WH. Pre-s1 antigendependent infection of Tupaia hepatocyte cultures with human hepatitis B virus. J Virol 2003;77:9511-9521.

53. Hong HJ, Ryu CJ, Hur H, Kim S, Oh HK, Oh MS, Park SY. In vivo neutralization of hepatitis B virus infection by an anti-preS1 humanized antibody in chimpanzees. Virology 2004;318:134-141.

54. Petcu DJ, Aldrich CE, Coates L, Taylor JM, Mason WS. Suramin inhibits in vitro infection by duck hepatitis B virus, Rous sarcoma virus, and hepatitis delta virus. Virology 1988;167:385-392.

55. Krepstakies M, Lucifora J, Nagel CH, Zeisel MB, Holstermann B, Hohenberg H, Kowalski I, Gutsmann T, Baumert TF, Brandenburg K, Hauber J, Protzer U. A new class of synthetic peptide inhibitors blocks attachment and entry of human pathogenic viruses. $\mathrm{J}$ Infect Dis 2012;205:1654-1664.

56. Petersen J, Dandri M, Mier W, Lutgehetmann M, Volz T, von Weizsacker F, 
infection in vivo by entry inhibitors derived from the large envelope protein. Nat Biotechnol 2008;26:335-341.

57. Volz T, Allweiss L, ḾBarek MB, Warlich M, Lohse AW, Pollok JM, Alexandrov A, Urban S, Petersen J, Lütgehetmann M, Dandri M. The entry inhibitor Myrcludex-B efficiently blocks intrahepatic virus spreading in humanized mice previously infected with hepatitis B virus. J Hepatol 2013;58:861-867.

58. Bogomolov P, Voronkova N, Allweiss L, Dandri M, Schwab M, Lempp FA, Haag M, Wedemeyer H, Alexandrov A, Urban S. A proof-of-concept Phase 2a clinical trial with HBV/HDV entry inhibitor Myrcludex B. Hepatology 2014;60:1279a-1280a.

59. Nkongolo S, Ni Y, Lempp FA, Kaufman C, Lindner T, Esser-Nobis K, Lohmann V, Mier W, Mehrle S, Urban S. Cyclosporin A inhibits hepatitis B and hepatitis D virus entry by cyclophilin-independent interference with the NTCP receptor. J Hepatol 2014;60:723-731.

60. Lucifora J, Esser K, Protzer U. Ezetimibe blocks hepatitis B virus infection after virus uptake into hepatocytes. Antiviral Res 2013;97:195-197.

61. Ko C, Park WJ, Park S, Kim S, Windisch MP, Ryu WS. The FDA approved drug irbesartan inhibits HBV-infection in HepG2 cells stably expressing sodium taurocholate cotransporting polypeptide. Antivir Ther 2015. In press

62. Blanchet M, Sureau C, Labonte P. Use of FDA approved therapeutics with hNTCP metabolic inhibitory properties to impair the HDV lifecycle. Antiviral Res 2014;106:111-115.

63. Kaneko M, Watashi K, Kamisuki S, Matsunaga $H$, Iwamoto $M$, Kawai $F$, Ohashi $H$, Tsukuda S, Shimura S, Suzuki R, Aizaki H, Sugiyama M, Park SY, Ito T, Ohtani N, Sugawara F, Tanaka Y, Mizokami M, Sureau C, Wakita T. A Novel Tricyclic Polyketide, Vanitaracin A, Specifically Inhibits the Entry of Hepatitis B and D Viruses by Targeting Sodium Taurocholate Cotransporting Polypeptide. J Virol 2015;89:11945-11953.

64. Dong Z, Ekins S, Polli JE. Structure-activity relationship for FDA approved drugs as inhibitors of the human sodium taurocholate cotransporting polypeptide (NTCP). Mol Pharm 2013;10:1008-1019. 
472 65. Huang HC, Tao MH, Hung TM, Chen JC, Lin ZJ, Huang C. (-)-Epigallocatechin-3473 gallate inhibits entry of hepatitis B virus into hepatocytes. Antiviral Res 2014;111:100-111.

474 66. Nathan C. Fresh approaches to anti-infective therapies. Sci Transl Med $475 \quad 2012 ; 4: 140 s r 142$.

476 67. Belloni L, Allweiss L, Guerrieri F, Pediconi N, Volz T, Pollicino T, Petersen J,

477 Raimondo G, Dandri M, Levrero M. IFN-alpha inhibits HBV transcription and replication in

478 cell culture and in humanized mice by targeting the epigenetic regulation of the nuclear

479 cccDNA minichromosome. J Clin Invest 2012;122:529-537.

480 68. Liu F, Campagna M, Qi Y, Zhao X, Guo F, Xu C, Li S, Li W, Block TM, Chang J, Guo

$481 \mathrm{JT}$. Alpha-interferon suppresses hepadnavirus transcription by altering epigenetic

482 modification of cccDNA minichromosomes. PLoS Pathog 2013;9:e1003613.

483

484

485

486

487

488

489

490

491

492

493

494

495

496

497

498

499 
501 Figure 1. Molecular mechanisms of HBV entry and entry inhibitors. HBV viral particles

502 first interact with hepatic HSPGs, including GPC5. This interaction is inhibited by a

503 monoclonal anti-GPC5 antibody or heparinase treatment. HBV then binds directly to NTCP at

504 the bile acid pocket site. Several NTCP inhibitors block this interaction and prevent HBV

505 entry,such as cyclosporin A, ezetimibe, irbesartan, vanitaracin A, ritonavir or

506 epigallocatechin gallate. A synthetic HBV-derived preS1 peptide (Myrcludex B) exhibits a

507 strong antiviral activity by competing with HBV for NTCP binding. After binding to NTCP, the

508 virus is internalized but the underlying mechanisms are still unknown.

509 Table legend

510 Table 1. Examples of HBV entry inhibitors targeting NTCP in hepatocytes

Table

\begin{tabular}{|l|l|l|l|}
\hline Name & Class & Development stage & References \\
\hline Myrcludex B & Myristoylated lipopeptide & Clinical phase II & {$[57]$} \\
\hline Cyclosporin A & Immunosuppressant & Cell culture & {$[44,59]$} \\
\hline Ezetimibe & b-lactam & Cell culture & {$[60]$} \\
\hline Irbesartan & Angiotensin receptor blocker & Cell culture & {$[61,62]$} \\
\hline Vanitaracin A & Fungal tricyclic polyketide & Cell culture & {$[63]$} \\
\hline Ritonavir & HIV protease inhibitor & Cell culture & {$[62]$} \\
\hline Epigallocatechin gallate & Green tea polyphenol & Cell culture & {$[65]$} \\
\hline
\end{tabular}




\section{Figure}

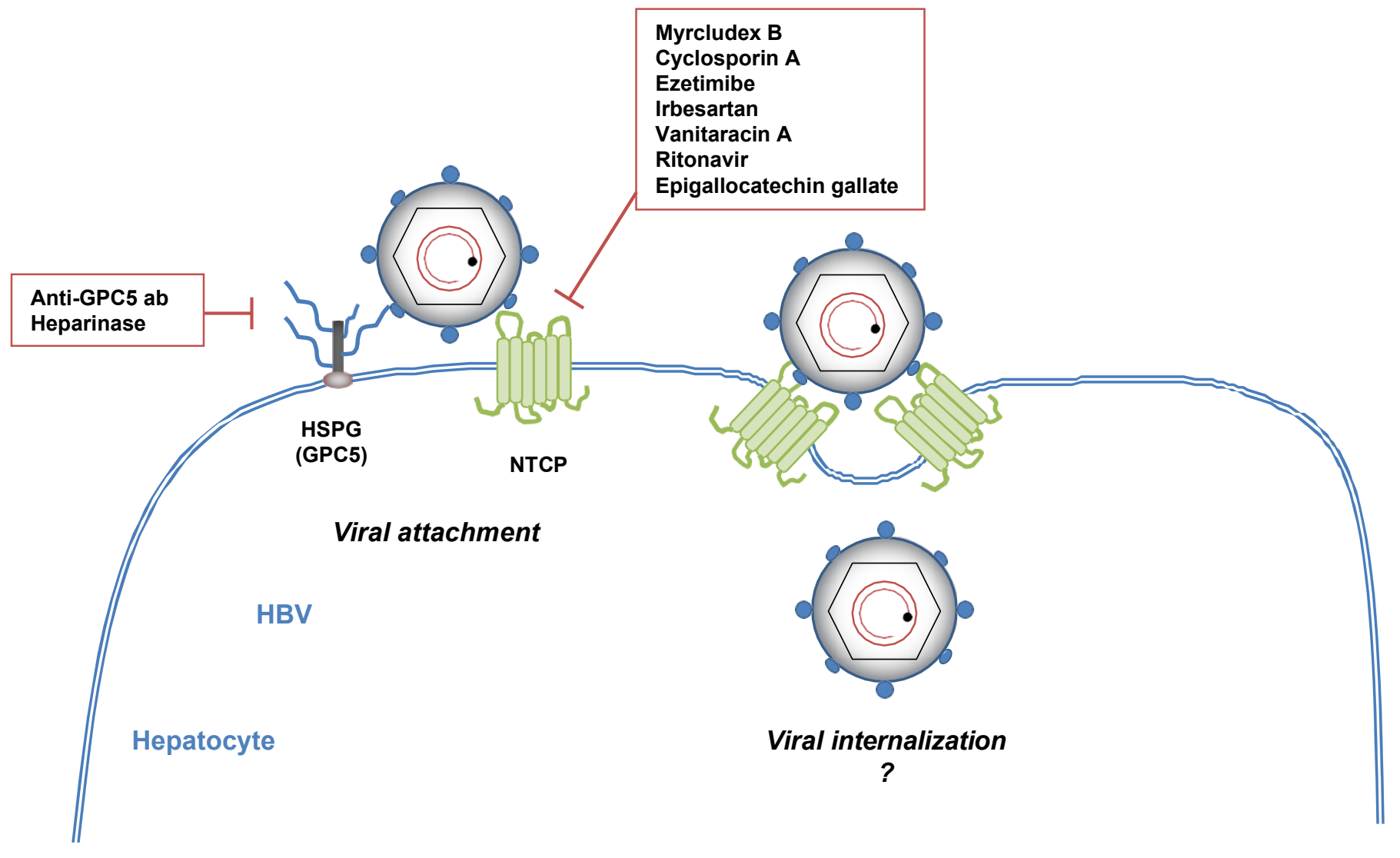

